\title{
Otrzymywanie i struktura kompozytowych warstw Ni-NbC napawanych plazmowo
}

\author{
Formation and structure of the composite coatings Ni-NbC \\ deposited by plasma transferred arc
}

\section{Streszczenie}

W artykule przedstawiono wyniki badań kompozytowych warstw Ni-NbC napawanych plazmowo z mieszaniny proszków na podłoża ze stali niestopowej. Napoiny te wykonano dla zmiennych wartości natężenia prądu łuku głównego w zakresie $60 \div 120$ A. Przeprowadzono badania struktury, stosując zarówno mikroskopię optyczną, jak i skaningową. Analizowano rozkład mikrotwardości osnowy. Wykazano, iż poprawne napoiny formują się dla określonych parametrów procesu, a w efekcie intensywnego oddziaływania cząstek NbC z ciekłą osnową dochodzi do ich dezintegracji.

Słowa kluczowe: napawanie plazmowe proszkowe; napoiny kompozytowe; Ni-NbC

\begin{abstract}
The results of investigations of $\mathrm{Ni}-\mathrm{NbC}$ composite coatings deposited by the plasma transferred arc welding method from a mixture of powders onto the low alloy steel are presented in the paper. These weld overlaying were made for variable values of the main arc current in the range of $60 \div 120 \mathrm{~A}$. The structure examinations of coatings were carried out using both optical and scanning microscopy. The microhardness distribution of the matrix of composite coatings was also analyzed. It was shown that correct weld overlaying are formed for specific process parameters, and as a result of the intensive interaction of $\mathrm{NbC}$ particles with the liquid matrix comes to their disintegrate.
\end{abstract}

Keywords: Plasma Powder Transferred Arc Welding; composite coatings; Ni-NbC

\section{Wstęp}

Napawanie plazmowe proszkowe jest często stosowaną techniką w modyfikacji bądź regeneracji warstwy wierzchniej części maszyn ze względu na swoje zalety [1]. Jedną z korzyści stosowania tej techniki jest możliwość otrzymywania napoin o szerokim zakresie składu chemicznego, w tym również warstw o strukturze materiału kompozytowego. Napoiny kompozytowe o osnowie metalicznej z dodatkiem wysokotopliwych faz, w postaci węglików, borków czy azotków łączą w sobie cechy stosunkowo plastycznej matrycy i twardych cząstek fazy umacniającej. Tego typu warstwy wykazują jednocześnie wysoką odporność na zużycie w warunkach dużego obciążenia ściernego i udarowego $[2,3]$.

Wysokie właściwości eksploatacyjne wykazują napoiny kompozytowe umacniane węglikami metali przejściowych z IVB-VIB grupy układu okresowego pierwiastków. Stosunkowo dużo prac poświęconych jest wszechstronnym badaniom struktury i odporności na zużycie napoin o osnowie niklu

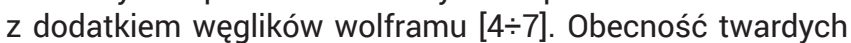
cząstek WC/W2C znacząco podnosi odporność na zużycie tych napoin. Prowadzone są też prace dotyczące napoin

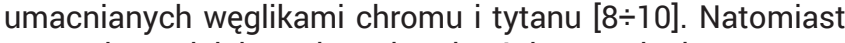
znacznie mniej jest danych odnośnie napoin kompozytowych umacnianych cząstkami pozostałych węglików metali przejściowych, np. ZrC, HfC, NbC, TaC czy MoC. Fazy te charakteryzują się równie atrakcyjnymi właściwościami przez co ich dodatek znacząco poprawia właściwości napoin [11].

W pracy tej stanowiącej kontynuację wcześniejszego cyklu badań $[12,13]$ przedstawiono aspekty związane z otrzymywaniem i charakterystyką struktury powłok kompozytowych Ni-NbC otrzymywanych techniką plazmową dla różnych parametrów.

\section{Stosowane materiały}

Kompozytowe napoiny napawano na podłoża ze stali niestopowej typu S355J0. Do badań przygotowano płaskowniki o wymiarach $10 \times 50 \times 150 \mathrm{~mm}$. Przed procesem napawania powierzchnia stalowych płytek była dokładnie czyszczona poprzez obróbkę śrutowania.

Dr inż. Mariusz Bober - Politechnika Warszawska.

Autor korespondencyjny/Corresponding author. mbober@wip.pw.edu.pl 
Do napawania wykorzystano mieszaninę złożoną z proszków osnowy i fazy umacniającej. Osnowę stanowił komercyjny proszek na bazie niklu o symbolu DA 22 zawierający dodatkowo $0,03 \%$ C, $2,4 \%$ Si, 1,4\% B oraz 0,4\% Fe. Proszek osnowy mieszano z proszkiem węglika niobu w stosunku objętościowym 60:40. Z danych producenta wynika, iż ziarnistość proszku DA 22 mieści się w przedziale $50 \div 150 \mu \mathrm{m}$ a jego kształt jest sferyczny. Natomiast z uwagi na brak informacji odnośnie rozmiaru frakcji NbC przeprowadzono analizę sitową tego proszku i wyodrębniono frakcję o ziarnistości 45 $\div 160 \mu \mathrm{m}$. Do wykonania analizy sitowej wykorzystano przesiewacz laboratoryjny Retsch AS 200 Control.

Morfologię proszków węglika niobu przedstawiono na rysunku 1, na którym widoczne są nieregularne cząstki NbC o rozwiniętej powierzchni.

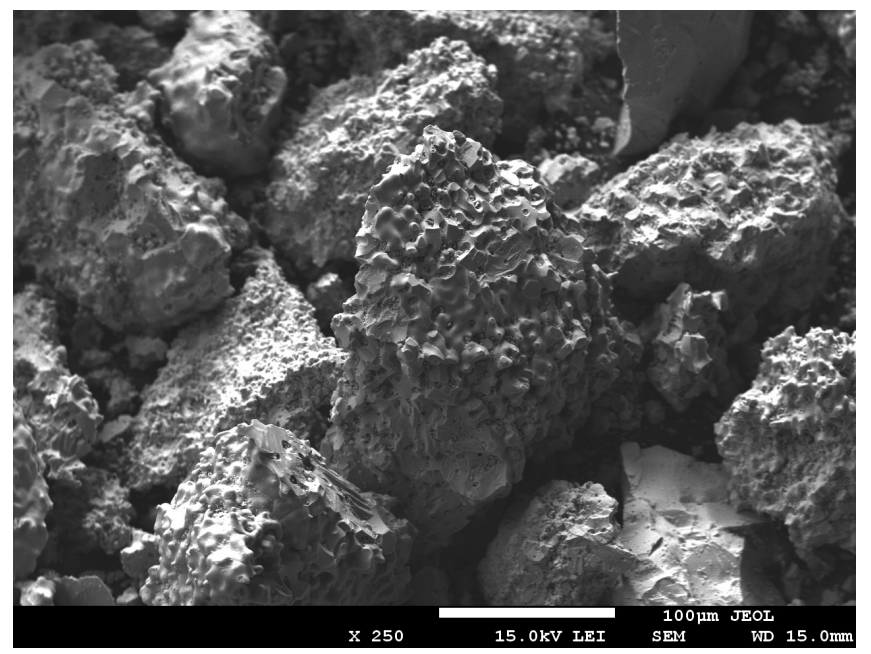

Rys. 1. Morfologia ziaren proszku NbC

Fig. 1. The morphology of the $\mathrm{NbC}$ powder grains

\section{Przygotowanie próbek}

Proces napawana plazmowego prowadzono stosując urządzenie PTA 301 Control M firmy Hettiger. Na podstawie wcześniejszych badań $[14,15]$ ustalono stałe i zmienne parametry procesu. Kompozytowe napoiny wykonano dla zmiennych wartości natężenia prądu łuku głównego mieszczących się w przedziale $60 \div 120 \mathrm{~A}$. Pozostałe parametry zachowano na stałym poziomie, a ważniejsze z nich wymieniono poniżej:

- natężenie prądu łuku wewnętrznego - $40 \mathrm{~A}$,

- prędkość napawania - $50 \mathrm{~mm} / \mathrm{min}$,

- wydatek proszku $-6 \mathrm{~g} / \mathrm{min}$,

- średnica dyszy plazmowej $-4 \mathrm{~mm}$,

- odległość plazmotronu od powierzchni napawanej - $15 \mathrm{~mm}$,

- zakres oscylacji - $8 \mathrm{~mm}$,

- prędkość ruchu oscylacyjnego - 450 mm/min,

- wydatki gazów (argon 5,0):

- plazmotwórczego - 1,5 I/min,

- osłonowego - $16 \mathrm{l} / \mathrm{min}$,

- transportującego proszek - $8 \mathrm{l} / \mathrm{min}$.

\section{Wyniki badań}

Po procesie napawania kompozytowe powłoki poddano badaniom makroskopowym. Obserwacje prowadzono okiem nieuzbrojonym. Na ich podstawie ustalono, iż warstwy wykonane przy najmniejszym natężeniu prądu (60 A) posiadają nieregularny kształt lica i z tego powodu nie były dalej badane.
Z pozostałych napoin wycięto próbki do badań mikroskopowych. Każdy ścieg został przecięty w stałej odległości od początku napoiny. Zgłady metalograficzne przygotowano wg standardowej procedury. Do obserwacji i rejestracji mikrostruktury wykorzystano stanowisko wyposażone w mikroskop metalograficzny Olympus BX51 z cyfrowym zapisem obrazu.

$\mathrm{Na}$ rysunku 2 przedstawiono struktury napoin kompozytowych otrzymanych dla natężenia prądu łuku głównego 70 i 80 A. W napoinach tych widoczne są duże pęcherze gazowe oraz przyklejenia na granicy powłoki ze stalowym podłożem. Pęcherze gazowe formują się na ogół na granicy międzyfazowej węglik-osnowa, co świadczyć może o niedostatecznej zwilżalności NbC ciekłym stopem $\mathrm{Ni}$.
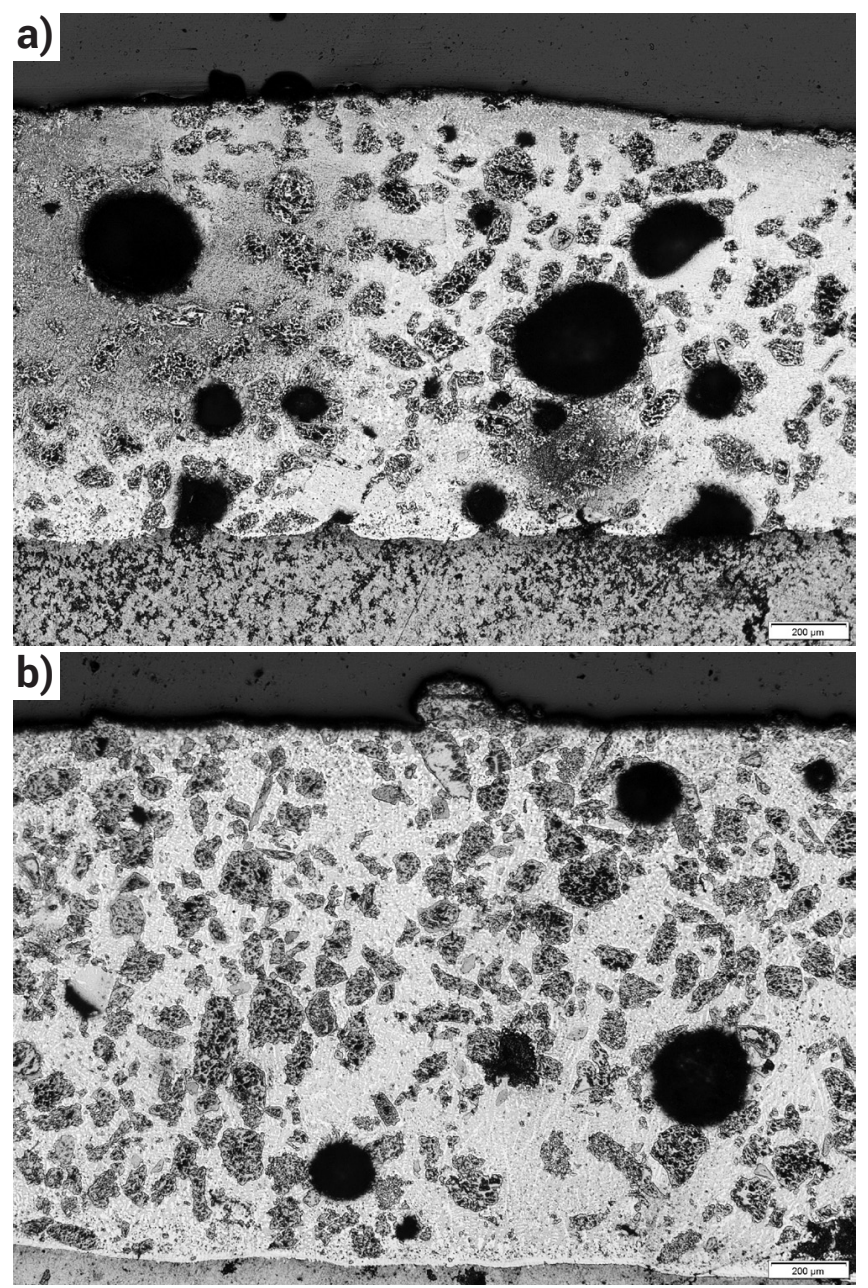

Rys. 2. Niezgodności spawalnicze $w$ napoinach kompozytowych wykonanych przy natężeniu prądu: a) $70 \mathrm{~A}$, b) $80 \mathrm{~A}$

Fig. 2. The welding discrepancies in composite coatings obtained with welding current: a) $70 \mathrm{~A}$, b) $80 \mathrm{~A}$

W warstwach napawanych z większą energią liniową nie obserwowano wyżej wymienionych niezgodności spawalniczych. Na rysunku 3 przedstawiono przykład struktury napoiny kompozytowej Ni-NbC wykonanej przy natężeniu prądu $100 \mathrm{~A}$. Na tle osnowy rozmieszczone są ciemne cząstki węglika niobu. Nieliczne małe pęcherze gazowe zlokalizowane są w obszarze lica warstwy. Granica międzyfazowa napoina kompozytowa - stalowe podłoże jest ciągła i pozbawiona niezgodności spawalniczych.

Morfologię cząstek fazy umacniającej przedstawiono na rysunku 4. Na tle dwufazowej osnowy o strukturze dendrytycznej widoczne są duże oraz małe nieregularne cząstki węglika niobu. Obecność małej frakcji NbC spowodowana jest rozpadem dużych aglomeratów na skutek oddziaływania 


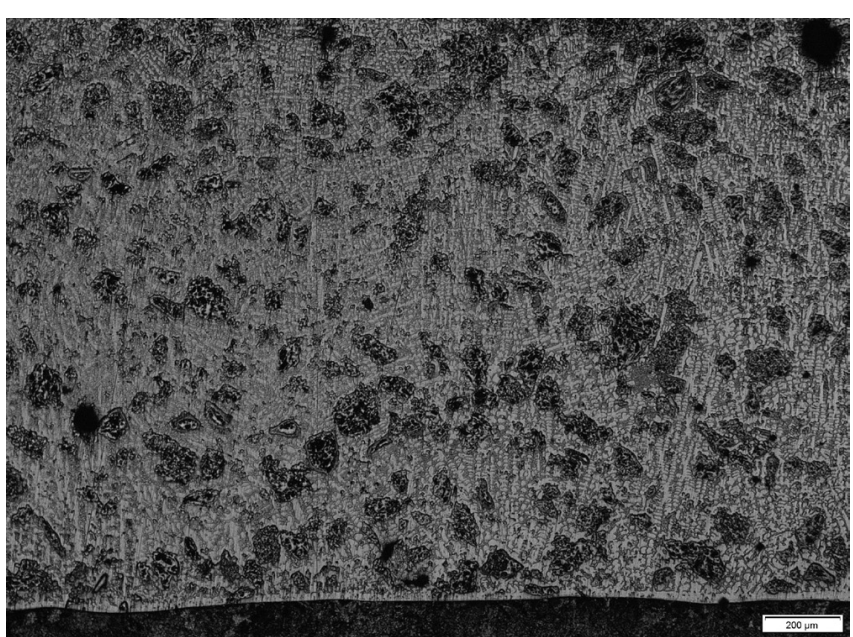

Rys. 3. Mikrostruktura napoiny kompozytowej Ni-NbC napawanej prądem o natężeniu $100 \mathrm{~A}$

Fig. 3. The microstructure of composite Ni-NbC coatings obtained with surfacing current of $100 \mathrm{~A}$

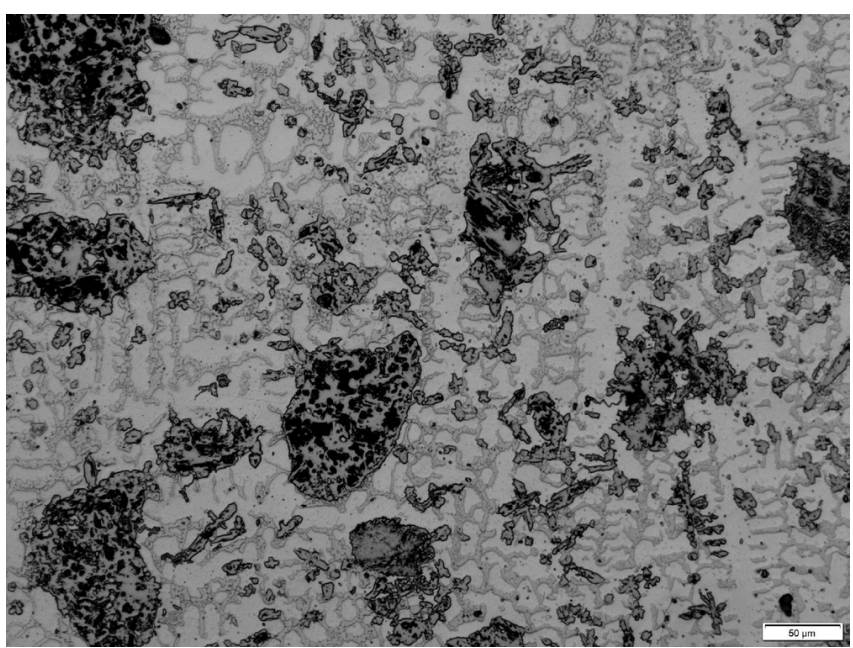

Rys. 4. Morfologia fazy umacniającej w kompozytowych warstwach $\mathrm{Ni}-\mathrm{NbC}$

Fig. 4. The strengthening phase morphology in $\mathrm{Ni}-\mathrm{NbC}$ composite coatings

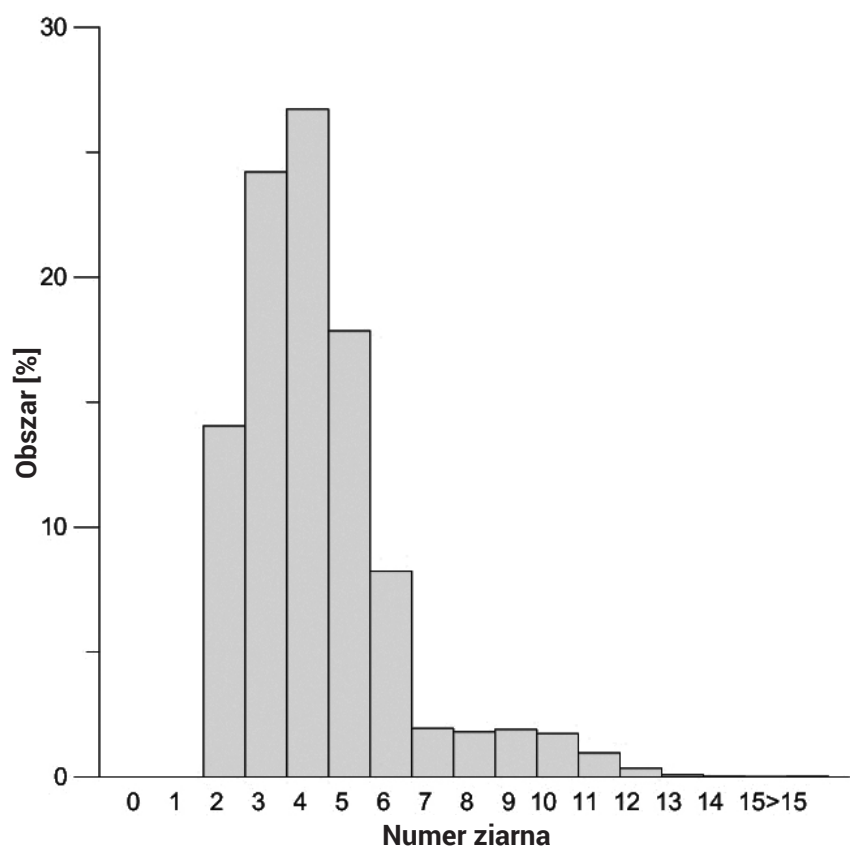

Rys. 5. Rozkład wielkości ziarna NbC w osnowie napoiny wg normy ISO 643:2012

Fig. 5. Grain size distribution NbC in overlaying matrix according to ISO 643:2012 standard ze strumieniem plazmy bądź w efekcie reakcji z ciekłą osnową. Na rysunku 5 przedstawiono histogram wielkości ziarna $\mathrm{NbC}$ w napoinach kompozytowych. Badania te wykonano za pomocą programu Enterprise Stream firmy Olympus. Z danych tych wynika, iż rozmiar najmniejszej frakcji NbC wynosi nawet poniżej $2 \mu \mathrm{m}$, a więc jest znacznie mniejszy niż w wyjściowej mieszaninie proszków.

Badania mikroskopowe prowadzone przy większych powiększeniach ujawniają obecność osnowy we wnętrzu dużych cząstek węglika niobu (rys. 6), a zatem dochodzi do penetracji ciekłej osnowy po granicach ziaren $\mathrm{NbC}$ i dezintegracji dużych cząstek. W efekcie formują się drobne frakcje węglika dość równomiernie rozmieszczone w osnowie. Granica międzyfazowa węglik-osnowa jest ciągła bez wyraźnej strefy reakcji. Świadczą o tym także mapy rozkładu pierwiastków stopowych - rysunek 7 . Badania te potwierdzają obecność niklu i żelaza w przestrzeniach dużych aglomeratów NbC, jak również obecność niobu w osnowie.

Pomiar mikrotwardości osnowy wykonano na zgładach metalograficznych w osi napoiny prostopadłej do linii wtopienia. Badano twardość napoin wykonanych dla natężenia prądu 100 i 120 A. Wyniki badań przedstawiono na rysunku 8.

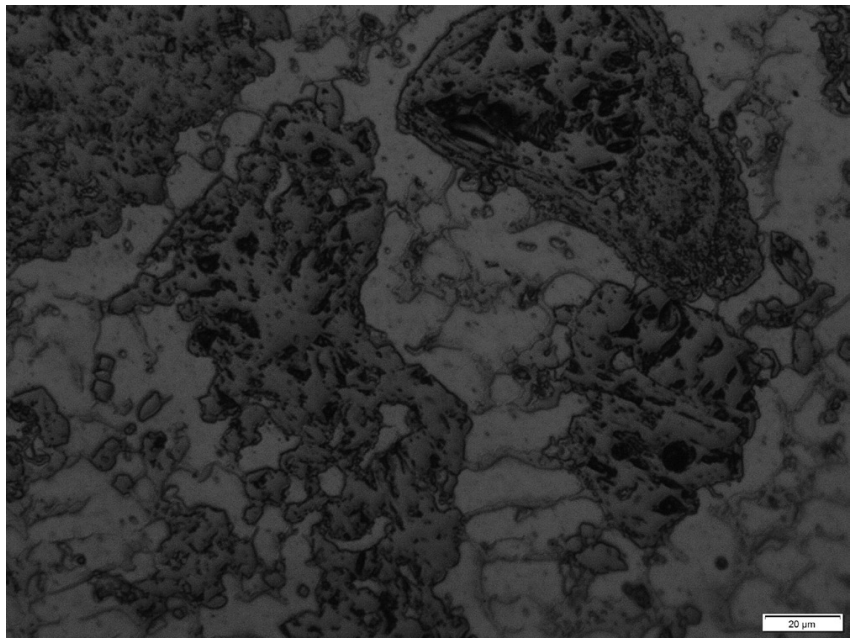

Rys. 6. Dezintegracja dużych aglomeratów NbC

Fig. 6. Disintegration of large $\mathrm{NbC}$ agglomerates

\section{Omówienie wyników badań}

Przeprowadzone badania dowodzą, iż poprawne napoiny kompozytowe Ni-NbC formowały się dla stosunkowo wysokiego natężenia prądu łuku głównego, tj. powyżej $90 \mathrm{~A}$. Zbyt mała energia liniowa procesu napawania jest przyczyną powstawania niezgodności spawalniczych w postaci przyklejeń napoiny do materiału podłoża (rys. 2a) oraz dużych pęcherzy gazowych (rys. 2b). Wraz ze wzrostem natężenia prądu ilość pęcherzy gazowych znacząco zmniejszała się. Obecność pęcherzy gazowych można rozpatrywać w dwóch aspektach. Na rysunku 2 widać, że pęcherze te zlokalizowane są na granicy międzyfazowej węglik-osnowa. Świadczyć to może o niedostatecznej zwilżalności cząstek fazy umacniającej ciekłym stopem Ni. Według danych literaturowych [16] w węglikach metali przejściowych IVB-VIB grupy układu okresowego dominuje metaliczny charakter wiązania chemicznego, lecz z pewnym udziałem wiązań kowalencyjnych, a nawet jonowych. Rodzaj wiązania chemicznego jest kluczowym czynnikiem decydującym o zwilżalności cząstek fazy umacniającej ciekłą osnową metaliczną. Trudności w formowaniu napoin oraz obecność niezgodności spawalniczych 




$50 \mu \mathrm{m}$

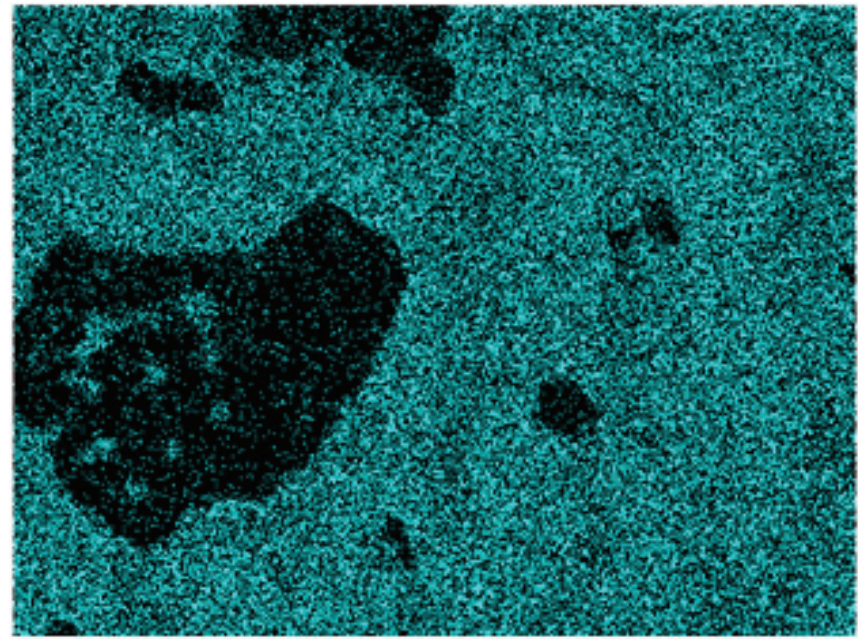

Fe Ka1

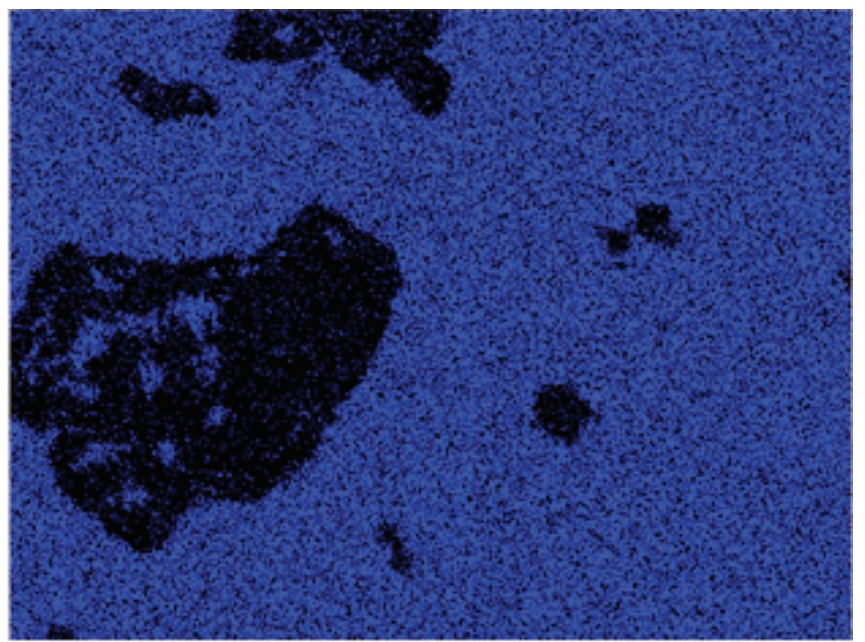

Ni Ka1

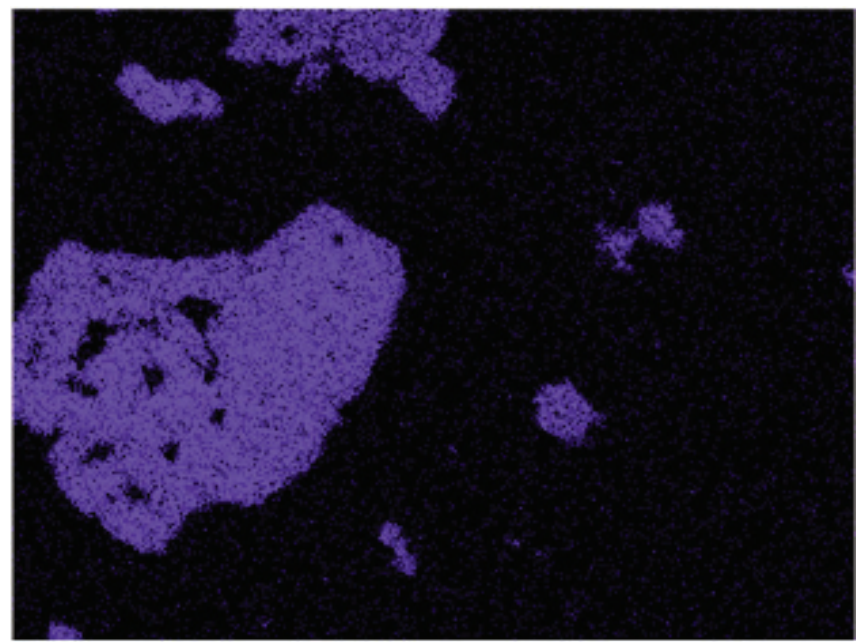

$\mathrm{Nb}$ La1

Rys. 7. Mikrostruktura granicy międzyfazowej węglik-osnowa oraz powierzchniowe rozkłady $\mathrm{Nb}$, Fe i Ni Fig. 7. The microstructure of the carbide-matrix interface and surface distribution of $\mathrm{Nb}, \mathrm{Fe}$ and $\mathrm{Ni}$

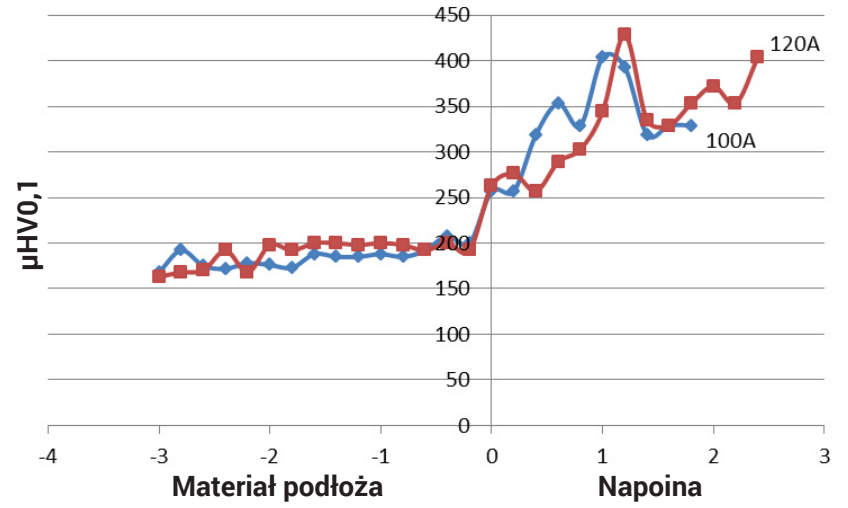

Rys. 8. Rozkład mikrotwardości osnowy

Fig. 8. Distribution of matrix microhardness

pośrednio świadczą o pewnym udziale wiązań kowalencyjnych i/lub jonowych w NbC. Natomiast wzrost natężenia prądu skutkował aktywacją termiczną procesu zwilżania stąd napoiny kompozytowe formowały się poprawnie. Drugi aspekt obecności pęcherzy gazowych może wynikać z morfologii ziaren $\mathrm{NbC}$. Mianowicie mają one nieregularny kształt, a powierzchnia ich jest bardzo rozwinięta. Można także przypuszczać, iż są w pewnym stopniu porowate. Są to więc sprzyjające warunki do adsorpcji gazów. Małe natężenie prądu skutkuje krótkim czasem krystalizacji, a więc pęcherze gazowe zostają uwięzione we wnętrzu napoiny. Z kolei wzrost natężenia prądu prowadzi do większej objętości ciekłego jeziorka, tym samym wydłuża się czas krystalizacji, a w efekcie gazy te zostają uwolnione.

W napoinach kompozytowych Ni-NbC węglik występował w postaci zarówno dużych, jak i małych cząstek o nieregularnym kształcie (rys. 4). Analiza wielkości ziaren NbC wykazała, iż najmniejsze cząstki mają rozmiar poniżej $2 \mu \mathrm{m}$ (rys. 5), a więc są znacznie mniejsze niż w wyjściowej mieszaninie proszków. Obecność drobnej frakcji jest efektem dezintegracji dużych aglomeratów NbC w trakcie napawania. Występuje tu mechanizm penetracji ciekłej osnowy stopu Ni w głąb węglika i rozpuszczanie granic ziaren (rys. 6).

Badania granicy międzyfazowej węglik-osnowa wykazały, iż jest ona ciągła bez wyraźnej strefy reakcji pomiędzy tymi fazami - rysunek 7. Mapy rozkładów powierzchniowych Nb, Ni i Fe dokumentują to stwierdzenie. Nie mniej jednak z rozkładu powierzchniowego niobu wynika, że jest on obecny w osnowie, co wskazuje na nadtapianie węglika w trakcie napawania.

Mikrotwardość osnowy napoin kompozytowych nieznacznie zmniejsza się wraz ze wzrostem natężenia prądu - rysunek 8. Spadek twardości wynikający z większego udziału żelaza z nadtopionego podłoża nie jest wystarczająco kompensowany umocnieniem roztworowym osnowy niobem obecnym z nadtopionych węglików. Widać także wyraźną tendencję wzrostu twardości osnowy w kierunku od linii wtopienia do lica napoiny. 


\section{Wnioski}

- Formowanie się poprawnych napoin kompozytowych Ni-NbC zależy ściśle od energii liniowej procesu napawania. Zastosowanie natężenia prądu poniżej 90 A skutkuje tworzeniem się niezgodności spawalniczych w postaci przyklejeń i pęcherzy gazowych.

- W napoinach kompozytowych węglik niobu występuje w postaci dużych, jak i bardzo małych, cząstek o nieregularnym kształcie. Udział małej frakcji wynika z intensywnej reakcji ciekłej osnowy z NbC.

- Granica międzyfazowa węglik-osnowa jest ciągła bez wyraźnej strefy reakcji.

- Obecność niobu w osnowie świadczy o częściowym nadtapianiu węglika w trakcie procesu napawania plazmowego.

- Wzrost natężenia prądu prowadzi do nieznacznego zmniejszenia twardości osnowy w wyniku większego rozcieńczenia napoiny żelazem.

\section{Badania były finansowane z grantu NCBiR/KGHM nr CuBR/1/3NCBR/2014}

\section{Literatura}

[1] Jitai N., Wei G., Mianhuan G., Shixiong L.: Plasma application in thermal processing of materials, Vacuum 65, 2002, pp. 263-266.

[2] Katsich C., Badisch E.: Effect of carbide degradation in a Ni-based hardfacing under abrasive and combined impact/abrasive conditions, Surface \& Coatings Technology 206, 2011, pp. 1062-1068.

[3] Zhang G. S., JXing J. D., Gao Y. M.: Impact wear resistance of WC/Hadfield steel composite and its interfacial characteristics, Wear 260, 2006, pp. 728-734.

[4] Liyanagea T., Fisherb G., Gerlicha A. P.: Microstructures and abrasive wear performance of PTAW deposited Ni-WC overlays using different Nialloy chemistries, Wear 274-275, 2012, pp. 345-354.

[5] Kamdi Z., Shipwaya P.H., Voiseya K.T., Sturgeonb A.J.: Abrasive wear behaviour of conventional and large-particle tungsten carbide-based cermet coatings as a function of abrasive size and type, Wear 271, 2011, pp. 1264-1272.

[6] Bober M. Senkara J.: Badania struktury kompozytowych powłok Ni-WC napawanych plazmowo, Przegląd Spawalnictwa, vol. 88, nr 5, 2016, s. 67-70.

[7] Piasecki A., Bartkowski D., Młynarczak A.: Study of the surface layers of 18G2A steel after plasma surfacing with WC and Fe-Cr powders, Inżynieria Materiałowa, nr 2, 2014, pp. 179-182.

[8] Huang Z., Hou Q., Wang P.: Microstructure and properties of $\mathrm{Cr}_{3} \mathrm{C}_{2}-$ modified nickel - based alloy coating deposited by plasma transferred arc process, Surface \& Coatings Technology, 2008, No. 202, 2993-2999.
[9] Bourithis L., Milonas Ath., Papadimitriou G.D.: Plasma transferred arc surface alloying of a construction steel to produce a metal matrix composite tool steel with TiC as reinforcing particles, Surface and Coatings Technology 165, 2003, pp. 286-295.

[10] Bober M. Grześ J.: The structure of Ni-TiC composite coatings deposited by PPTAW method, Composites Theory and Practice, vol. 2, 2015, pp. 72-77.

[11] Hung F.Y., Yan Z.Y., Chen L.H., Lui T.S.: Microstructural characteristics of PTA-overlayed NbC on pure Ti, Surface \& Coatings Technology, 2006, No. 200, pp. 6881-6887.

[12] Bober M., Senkara J.: Badania porównawcze napawanych plazmowo warstw niklowych z węglikami Ti i Cr, Przegląd Spawalnictwa, nr 9, 2011, s. 32-37.

[13] Bober M., Senkara J.: Mikrostruktura kompozytowych powłok Ni-ZrC napawanych plazmowo, Przegląd Spawalnictwa, vol. 87, nr 10, 2015, s. 60-63.

[14] Bober M., Tobota K.: Badania istotności wpływu podstawowych parametrów napawania plazmowego na geometrię napoin, Przegląd Spawalnictwa, vol. 87, nr 9, 2015, s. 24-28.

[15] Bober M.: Badania wpływu głównych parametrów napawania plazmowego na geometrię napoin w oparciu o metody planowania eksperymentu, Przegląd Spawalnictwa, vol.89, nr 4, 2017, s. 5-9.

[16] Oyama S. T.: The chemistry of transition metal carbides and nitrides, Balckie Academic \& Professional, Chapman \& Hall, London, 199. 